\title{
[6]
}

\section{Home and Family}

In Taiwan, people often speak of the differences between life at home and life "outside, in society," where social relations are often described as fuza, "complicated." The family is the most private circle, but because long-term residents in a village or working-class neighborhood know most of each other's doings, the local community may become an extension of the home. In the working-class neighborhood in Taibei that I call Prosperity Settlement, during the unsophisticated late sixties men could appear at home or anywhere within the Settlement's boundaries in sleeping pajamas or underwear without anyone taking special notice. But they put on more formal clothing to go out into the wider world, or when representatives of that world came visiting. Most ordinary folk prefer the warmth and familiarity of home and family to the impersonality and possible dangers of "society," although there are always adventurous exceptions who seek out anonymity under the bright lights.

The coincidence of kinship ties, economic advantage, and the Chinese state's age-old tendency to treat families as primary social units makes families central to Taiwan's culture. Few extrafamilial sources of support or charity exist in Taiwan: government welfare services are extremely meager, and religious and other private charities are stretched thin, though the local temple procured fire relief for Miss Guo and her neighbors. For these reasons, as well as for the emotional ties they provide, Chinese strongly value, idealize, and identify with their families.

More than Americans, Chinese are conscious of the lifelong nature of family commitments, and are given to thinking of long-term effects on the whole unit of the actions of its members. Parents and grandparents plan for the education, occupations, and marriages of the young, basing their deci- 


\section{Chinese Working-Class Lives}

sions in large part on the effect the choice will have on the whole family. When Mrs. and Mr. Lim (introduced in Chapter 9) decide the family can afford a daughter-in-law and the children she will bear or adopt, they will urge their son to find a suitable girl and help him do so. His occupation as a future baker is being chosen for him-though in these enlightened times, he can veto the idea-to fit in with the realities of the family's good business location and none-too-productive fruit-and-ice shop. In contrast, the Zhangs, whom we will meet later in this chapter, failed to influence their sons, Bright Reputation and Bright Nation, to work in their dumpling restaurant, while Miss Guo's adopted son doesn't even visit her regularly. Family economic planning does not always work. But when it does, it contributes greatly to both stability and prosperity.

The smooth cooperation of family members is often disrupted by a determined individualism that, although not a part of the American stereotype of Chinese character, is encountered constantly in Taiwan's working class. Miss Guo's unconventional life and refusal to take help from her better-off sisters, Mrs. Lo's determination to keep her daughters and her willingness to leave her mountain for far-off Hainan Island, and Mrs. Zhang's Shandong outspokenness are the acts of tough people who know their own minds. They often find it hard to conform to the family-based decisions of others, as Mrs. Lim did so painfully in marrying her "brother." Being part of a family is not easy, but it is deeply valued, it brings practical rewards, and it is enshrined in an elaborate code of correct kinship behavior that is known to everyone.

The ideal Chinese family-promoted by the state, applauded in folklore, and put into practice most visibly by the elite of imperial days-is as perfect an example of patrilineal patriarchy as has been envisioned anywhere on earth. A man and his sons and grandsons, forming a property-owning corporation, ideally lived together in a continuously expanding household that might, in time, encompass a proverbial "five generations under one roof." These men and boys worked together under the control and authority of the eldest living male member of the senior generation, hierarchically ranked according to generation and birth order. All significant decisions were ideally made by the "family head," and were obeyed respectfully by his juniors. When this arrangement broke down and segments of the original household wished to go their own ways, the property was divided equally in shares among the senior men. Once the decision to divide the property had been made, the new segments became economically independent, each segment accepting the authority of its own family head. Under some circumstances-for example, when the need for large work groups or for defense against outsiders was especially strong-families 
organized themselves for work, war, and ritual as lineages, maintaining written records of their relationships over several generations. Some of these grew to thousands of members, controlling whole regions with many villages, especially in southern China (Freedman 1958 and 1966; Pasternak 1972).

Whether in families or lineages, men regularly worshiped the spirits of the men and women ancestral to them on domestic altars or in lineage temples. These rituals reminded the members of the debt they owed to senior generations in giving them life and the property on which they lived, reinforced the age hierarchy among living fathers and sons, and emphasized the centrality of men in kinship matters (Ahern 1973).

In this ideal version of kinship relations, women took a distinctly and overtly inferior place. Because she was considered less valuable than a son, almost not a member of the family, a daughter's only legitimate destiny was to marry and become a mother in some other family. Then, as a mother (especially of sons), her spirit would deserve a place on that family's altar as an ancestor after she died. Contemporary Taiwanese make such comments as, "She is only a useless daughter; we will have to feed her for years until she can do things, and then some other family will get the advantage." A woman had no right to the family property except for a dowry of clothes, furniture, and jewelry. When she married, she left her father's home forever; he had no obligation to take her back if she were divorced or widowed. In many societies, the marriage of a son and daughter is often seen as an opportunity to bind two previously unrelated families together in ties of in-lawship. In China, affinal relationships were often weakly developed, especially among agriculturalists, although they expanded to fill social vacuums when necessary (Gallin 1960; Gallin and Gallin 1985:101; Harrell 1982, chap. 4). While lineage "brothers" of a woman from an elite family might intervene to protect her from mistreatment in her marital home in order to maintain their own prestige (Freedman 1966:58-59), relatives of ordinary women were much less likely to take action against the man to whom they had given power over their sister or daughter (Pruitt 1945:30-32, 42). A married woman was transferred completely from her father's authority to her husband's (or husband's parents' while they lived); when widowed, she came under the legal guardianship of her son.

It was considered shameful and disgusting for a married woman, or even an engaged one, however young, to remarry should her spouse die. Families with "a chaste widow" of many years' standing could petition the imperial court for a grant to erect an archway over a road to commemorate her chastity. Women could not divorce except under extraordinary circumstances, and, since they could not return to their fathers' homes or easily 


\section{Chinese Working-Class Lives}

earn their own living except by prostitution, many unhappy wives preferred suicide to separation (M. Wolf 1975). A woman's children belonged solely and exclusively to her husband's family, whatever became of her. She was expected to act as a humble, servantlike daughter to her parents-in-law and to obey her mother-in-law in everything. Warm and affectionate relations between wife and husband were to be concealed, if they developed, for fear of the mother-in-law's jealous disapproval.

To assure that women would accept these tight constraints, a girl-child was raised very differently from a boy. Girls began to work at chores, tend babies, or do elaborate needlework while boys were still playing freely or in school. Because "stupidity in a woman is a virtue," girls were rarely educated, and in an act that both symbolized and realized their inferiority, the feet of many little girls were crippled by the breaking of the foot bones and binding the toes to the heel-an act of "beautification" that sometimes resulted in death.

Parents had absolute rights over their children, as men had over their wives. Husbands and fathers were ultimately responsible for agreeing to marriages, though the negotiations were usually arranged by women; it was impossible, both economically and legally, to marry without the agreement of the bride's and groom's fathers. Weddings were elaborate affairs in which a red-costumed virgin bride, paid for by a substantial bride-price and accompanied by a large dowry, was carried in a red sedan chair surrounded by musicians from her father's to her husband's parents' house. Marriage ritual clearly indicated that the transfer was to be final. Men could give out or adopt both boy and girl children, though the transfer of boys might require permission from the lineage. Though it was shameful to do so, men could sell their wives and children.

Families - again, ideally - achieved acceptance of these rules of family life both through economic and legal power, and through socialization. In a largely agricultural and very slowly growing economy, people needed membership in a family corporation to gain access to resources from which to gain a living. Custom and law upheld the rights of men and fathers to control the family and its resources. The Qing dynasty punishment for a son who killed his father was the same as that for high treason-being slowly cut into pieces (van der Sprenkel 1962:62).

In the young, however, rebelliousness was more commonly controlled not by the legal violence of the state, but by the intense socialization of children, especially in the principles of xiao, commonly translated "filial piety." Xiao, meaning complete submission to parents, is reckoned as one of the highest of Chinese virtues and the key to the maintenance of the hierarchical family structure. 
Even in the preindustrial past, the reality of the Chinese family was considerably more complex than the simple model just described, though that model was, and still is, constantly present as a guide to conduct. Differences in families' economic bases varied the degree of adherence to the model. Sons of a rich father with much property had more to lose through disobedience or independence than sons of a man with nothing to give them; brothers who inherited agricultural land might find it easier to continue a cooperative family corporation than men who worked for wages (Freedman 1966:47). Among the very poor, marrying even one son might exhaust the family's resources, so second and later sons were often unable to marry and expand the household. Here and there, when the penetration of industrialization made women's labor especially valuable, as in the silkspinning areas of Guangzhou, women sometimes rebelled at their subordinate roles in the patrilineal system by refusing to marry and setting up cooperative living arrangements with other women (Sankar 1984; Stockard 1985; Topley 1975). Even where families took on a form close to the ideal, women created informal "uterine" families made up of themselves and their children within the partrilineal households, using the intimacy of mother and child to bind sons more closely to themselves than to the authoritarian fathers (M. Wolf 1972). These segments of larger families struggled for autonomy, often prompting the division of brothers' families or the separation of sons from fathers. Regional differences further complicated the variations in agricultural labor needs, population, fertility, and the degree of control over families exercised by lineages and the state.

Taiwan in this century has displayed considerable variation in family patterns, particularly as these are affected by marriages and adoptions, two of the primary institutions for controlling family form. Certain departures from the simple patrilineal model of family relations result from the natural uncertainty of reproduction. In Taiwan, as in other parts of China, families who produced no adult sons needed to supply this deficiency to meet their family's requirements for labor, care for the aged, and ancestral worship. A family could adopt a son from a poor household with surplus boys; this usually required a substantial payment to the boy's natal parents. The adoption of a son from outside the family's agnatic kin was and is considered a risky business: adopted sons, such as Miss Guo's, are notoriously unfilial in adulthood. Families that could not afford to buy a son would try to persuade a man whose own family had nothing to leave him to marry their daughter, live in their home, and take their surname in an uxorilocal marriage. It was shameful for a man to abandon the responsibilities and ties to his own parents, as symbolized by his surname, and in doing so, he gave up all claim to his patrilineal relatives' property (Ahern 1973:121-25). An 


\section{Chinese Working-Class Lives}

uxorilocally married man could try to negotiate to keep his own name, and perhaps one or more of the children he fathered, to carry on his own line of descent.

North Taiwan has been the locus of kinship patterns that simultaneously display a particularly strong male bias in form while giving considerable decision-making power over adoption to women. Arthur Wolf and Huang Chieh-shan (1980) have analyzed this system, whereby, throughout much of the nineteenth century and the first third of the twentieth century, rural families gave or sold out to adoption up to 70 percent of girl babies within their first few months or years of life. These babies were usually adopted and nursed by women who had just given birth to girls of their own, who in turn were given away to other families. Such a girl, called a simpua, or "little daughter-in-law," was destined after puberty to become the wife of a son of her adoptive family in a simple ceremony. By bringing up a daughterin-law (a "minor marriage," in Wolf's term) instead of looking for an adult bride when the son was grown, Taiwanese parents spared themselves not only the expense of a traditional wedding, but the difficulty of training a grown woman in the ways of her mother-in-law. This arrangement also limited the degree of interest a girl's natal relatives would express in her welfare, giving her husband's family a completely free hand with her. Because the young couple, raised as brother and sister, usually found the relationship sexually "uninteresting," simpua marriages had the additional effect of undermining any potential for the "disloyal" affection between a son and his wife that mothers especially feared. All in all, it was an extraordinarily neat solution to one of the greatest problems of the ideal family, as seen from the parents' point of view.

Wolf and Huang argue that, in north Taiwan at least, the only reason there were any "major marriages" (those between adult women and men) was that some families raised their own daughters as insurance against having no sons. As a result, there were never enough girl children put up for adoption to meet the demand for simpua and minor marriages (1980:251-60, 272-81).

As the Japanese brought greater prosperity and diversified occupations to Taiwan, work opportunities that gave young people the option of rebelling a little against parental authority opened up. By the 1930s, so many young men were refusing to marry the simpua they had grown up with that the system broke down. Fewer girls were adopted, ${ }^{1}$ and of those who were, most married outsiders when they grew up. Mrs. Lim (Chapter 9), coming

1. Adopted daughters in their teens and twenties were still common before 1980; both Arrigo (1984:125-32) and Kung (1983:97, 119, 142) encountered them among factory workers. 
of age at about this time, accepted her families' arrangements for her as a filial daughter was trained to do. Her husband/brother, himself adopted and not much trusted by his suspicious foster mother, was not secure enough in the Lim family to object either. They are an unusual couple, because despite their dislike for the marriage, it has endured and produced a large number of children, uncommon in simpua marriages (Wolf and Huang 1980:161-77).

Marriages of young adults in Taiwan slowly ceased to be arranged entirely without the bride's and groom's knowledge or consent early in this century. It became customary for parents, having located and investigated a suitable prospect, to arrange for the young people to meet, well chaperoned, to look each other over. As more young people attended schools, groups of classmates helped each other find partners, providing respectable opportunities for acquaintanceship before the young couple turned the formalities over to their parents. Occasionally today, one hears of a couple who has married without involving their parents-it can be done in a simple civil ceremony-but this is still considered shocking and ill bred. At present, young working-class women and men seem more likely simply to live together without any form of marriage than to attempt the formalities without parental backing. Parental control over young people's marriage plans is therefore still strong among working-class Taiwanese, where both brideprice and dowry continue to accompany most marriages. For these, and for the lavish feasts that make a wedding joyful and legitimate rather than a shady private transaction, young people still need their family's assistance and consent.

Expanding economies on China's mainland coasts similarly affected the control of parents over children in the first half of this century. Married Mainlander immigrants had often known and courted their spouses before marriage, like the reluctant Mr. Zhang-though Mr. Kang's marriage was arranged for him by his parents (Chapter 6). Many Mainlanders' expectations about marriage were not, perhaps, very different from those of more urban Taiwanese when they arrived in the forties. But their arrival strongly influenced Taiwanese marriage patterns.

Wolf and Huang have calculated that it cost as much to raise a simpua as to pay for a son's wedding, but that for most people, it was more convenient to spend the money in small sums over the years (and also have the simpua's help around the house) than save it up and spend it all at once: "A simpua was a kind of savings account" (1980:271). The cost of a major marriage lay primarily in the brideprice negotiated for the bride's parents by a matchmaker. During the Japanese period, the necessary sum, along with the other wedding expenses, could take a farm family ten or fifteen years to 


\section{Chinese Working-Class Lives}

accumulate (Wolf and Huang 1980:269). Traditionally, the bride's family spent far more than they received in brideprice for an elaborate dowry with which she furnished the room in her parents-in-law's house, where she and her husband would live. The gold jewelry that was always included, along with some other gifts of money, remained the private property of the bride (M. Cohen 1976:178-91). Grooms' families, then, received most of the brideprice back as dowry, and brides' families were out of pocket for raising the girl and for certain engagement and wedding expenses (see Harrell and Dickey 1985).

When the Mainlanders, predominantly men who had come to Taiwan without families, began to seek wives in the fifties, they created a strong upward pressure on brideprices. As brideprices rose, the value of daughters was enhanced; some parents became eager to profit from marrying off their daughters. Taiwanese men, undercut in the marriage market by the Mainlanders' advantages, resented the newcomers more than ever.

The postwar reemphasis on brideprice may have slightly reversed the earlier tendency for the greater independence of young people: daughters, as they became valuable resources to manipulate in the marriage market, and sons, as they needed greater family assistance to amass higher brideprices in the more competitive market, came back under strong parental authority. Also, the generation that came of age in the bad economic years from the late thirties to the late fifties had fewer work opportunities to give them a degree of independence. But families responded differently to these pressures. Today, parents vary widely in how much independence they will accept in marriage decisions from their children, and in the degree to which a large brideprice is seen as essential to a working-class marriage. Miss Guo was "embarrassed" to ask for money for her daughters-her sonsin-law were poor men. Mrs. Zhang's in-laws asked for a brideprice of NT $\$ 40,000$ (U.S. $\$ 1,000$ ) but returned all but a token NT $\$ 4,000$ (U.S. $\$ 100$ ). Although a return of some of the negotiated price is customary, this was a generous return.

Changes in marriage practices reflect relatively slow responses to changing economic and population circumstances, but the change in the acceptance of divorce amounts to almost a revolution in Taiwan in recent years. Divorces are vanishingly few among the thousands of marriages recorded in the household registries for Prosperity Settlement from 1905 to 1970, although informal separations and the setting up of secondary, nonlegalized unions certainly occurred. Several of my older women acquaintances, whose husbands have long since left home to live with other women and the children these "little wives" have borne them, refuse legal divorce, even where the husband makes no contribution to their households. "I'm just an 
old-fashioned Shandong woman," said one of them, "and I couldn't stand to lose that much face."

In 1980 government figures quote the divorce rate as eight-tenths per thousand (DGBAS 1981: Table 18)-twice what it was from 1959 to 1974 (compared with thirty-eight per thousand in the United States [Population Reference Bureau 1977]). While divorce is still uncommon by Western standards, its increasing frequency shocks Taiwan's Chinese. During my 1980 visit, friends often mentioned the growth in divorce and the new attitudes people were beginning to express toward it. The Zhangs' discussion of their sons' marital careers in this chapter shows both the parents' distress and their resignation over their inability to control the shape of their families through settling their children in permanent marriages.

Although parents in Taiwan now deviate from the ideal that they alone should decide about the marriages, adoptions, and divorces that shape the family, family form has not changed as radically as one might imagine. For working-class people (and for other classes as well),membership in a large family with several occupations and a wide social network is still very useful. Family backing for education, job hunting, marriage, access to capital, and many other goals still makes their achievement easier than individual effort alone. Poorer, wage-earning working-class households seem a little more likely to separate into nuclear families than do better-off business households; but as the latter educate their children for whitecollar and technical professions, they, too, often fragment into smaller units.

Economic advantage or its absence shapes families, as does the culturally sanctioned ideal of a large, multigeneration family. This concept seems to appeal more to people as they grow older and hold more authority in such households. The struggle that many Chinese families endure between the older generation that wishes to keep the family together and the younger generation that prefers some independence and privacy does not mean that ideal family of old will soon disappear; many of today's "conservative" parents wanted and even achieved greater independence when they were young. In Taiwan, 75 per cent of couples live part of their lives in multigeneration families (Chu 1969:163-65). A domestic cycle of expansion, breakup, and rebuilding remains the norm for working-class families now as it has in the past. In 1970 in Prosperity Settlement, of a total of 109 families, 58.8 percent of the families but only 36.7 percent of individuals lived in fragmentary or nuclear families, while 42.2 percent of families and 63.3 percent of individuals lived in more complex families. In these households the average number of members of the more complex families was 10.59 (Rohsenow 1973:59), with one family numbering 27 persons. In a somewhat 


\section{Chinese Working-Class Lives}

similar neighborhood on the far side of Taipei City in the same year, Tang Mei-chun (1978:66) counted 75 percent nuclear and fragmentary families and 25 percent more complex units; he omits information on the numbers of individuals who live in these settings.

Americans emphasize "love" as the cement of family relations. Especially within the nuclear family, love between husband and wife, parent and child, and sibling and sibling is held in very high regard. When "love" ceases, those who formerly loved each other are thought to be acting appropriately if they terminate or diminish the relationship. Divorce, leaving home, and ceasing to contact family members are common and, though perceived as regrettable, accepted ways of behaving. By contrast, "love" is rarely invoked in explaining or maintaining Chinese families. Instead, xiao (submission to parents), duty, and obligation are the feelings that people usually describe when speaking of families. Wives and husbands do not expect to love each other romantically-though young people hope they will and family happiness seems to be greater when they do--and they are not expected to show their affection publicly. Chinese fathers especially feel they will lose authority if they are less than stern (Diamond 1969:35; M. Wolf 1970:41), so children who love their fathers may find their feelings impossible to show in direct ways. A young teacher once shyly confessed to me that he voluntarily performed the extremely old fashioned ketou (from which we get the English word "kowtow"-kneeling and bowing his head to the floor) to his father at the New Year because it was the only way he could express his deep love and respect for his severe parent.

Love plays a more overt part in the relations between mothers and children. A woman belongs securely to her husband's family only through her children, especially her sons, who become her allies, if necessary, against the rest of the family (M. Wolf 1972:32-37). She may need her sons' love to assure her of kindly treatment in old age, and throughout her life her children may be the only people whom she can freely love. The selfsacrificing, all-forgiving, wise mother is a cultural stereotype of considerable power in Chinese culture, and many sentimental movies and stories resolve their plot problems through a heroic mother's love.

Mothers and married daughters may also retain close ties now that the strict rules about the separation of a bride from her family have grown looser. Many women informants have observed to me that in modern times, daughters are closer to mothers than are sons, who now become "too attached" to their wives and neglect their mothers. "If you see a grandmother taking care of a baby nowadays, it's a good guess the child is her daughter's, because a woman feels closer to her daughter's children through 
love for the daughter," a perceptive young woman with a new baby told me. Affection among siblings, and especially between sisters, can be an important source of emotional support as well, but ties between brothers, inhibited by tensions over property and family responsibility and by the emotional restraint expected of men, do not always offer much intimacy as the brothers mature.

As in other relationships, attachment between parent and child is expected to take a tangible form. Parents support and nurture children while they are too small to help themselves. As they grow up, children's earnings properly belong to their parents, especially the mother, who normally keeps the family purse. In old age, parents can properly claim the right of support from their sons. During the children's maturity, however, when they have young ones of their own to feed, daughters and sons show their love and sense of responsibility most directly through money presents, especially at lunar New Year. Parents who receive red envelopes of money at these times know they are respected and feel they have raised their children well.

Families symbolize their unity and continuity by regular rituals that focus on the deceased relatives who gave living members their lives and property. In the main room of a dwelling where visitors are entertained, most Taiwanese working-class people maintain a domestic altar on which they keep slips of wood with ancestors' names on them in decorated boxes. Mainlanders usually do not set up such altars, in part because most do not know whether their parents have died yet or not. As time passes and the certainty that their parents must by now be dead grows, some set up temporary altars at the New Year, where they make prayers and offerings. This is especially likely to occur when a Mainlander man has married a conscientious Taiwanese woman who wishes to do her filial duty by her husband's family, while at the same time setting a good example for her children. Christians and agnostics, who are fairly common among Mainlanders, omit these ceremonies.

In Taiwanese households, the more punctilious housewives offer the ancestors tea, incense, and prayers every day. They commemorate the death days of many patrilineal relatives each year by a small feast of the dead person's favorite foods, which the dead person's spirit is invited to attend, along with the living family. And they invite their ancestors as a group to join the family at especially good dinners on the first and fifteenth of every lunar month (in business families, on the second and sixteenth), at the New Year, on other major ritural holidays, and at special family events like weddings. Hardly a week passes in a large and filial household when 


\section{Chinese Working-Class Lives}

ancestors are not called to be present among the living. This creates constant reminders of the duties the juniors owe their seniors, and of the unrepayable debts of life and property owed to them.

Families celebrate engagements, weddings, and the successful completion of the first month of life of babies by inviting guests for a feast; but they reserve their most spectacular and public displays of household rituals for funerals, especially when an old person with many descendants dies. Such a ceremony, in which so many details of performance concretize and reinforce the sense of obligation owed by the younger to the older family members, is most instructive for the anthropologist as well as for the participants.

Town families usually celebrate wedding feasts privately in restaurants and hotels, but the Taiwanese conduct funerals at home. In the cities, because dwellings are small, this means that many essential parts of the ritual are quite public. Even Mainlanders, who often hold simplified services at funeral parlors, escort their dead to their graves in lengthy public processions that include bands playing surprisingly cheerful Western marches. The approach of cacophonous traditional funeral music is still one of Taibei's most characteristic sounds, drawing attention to the formal display of filiality that all families wish to make for their dead.

When death occurs in a working-class neighborhood, the family pastes a white sign on their house front. All nearby neighbors ward off the possible ill effects of contact with the dead by putting up red pieces of paper over their doors. Family members wash the body, dress it in clean clothing, and place it in a tightly sealed coffin. Because it is unseemly to rush a relative into the grave, and because there are expensive preparations to be made for the funeral, the coffin remains in the main living room for a few weeks or even months. During the time, the deceased's spirit is thought to hover near the body, very aware of how it is treated. It requires food offerings at a temporary, white-draped altar in the main room at mealtimes and is soothed by the regular and formalized wailing and prostrations (ketou) that its living relatives perform. When relatives are attending its needs, they don special burlap sack or white clothing-a special costume for each significant kinship category (A. Wolf 1970b).

For a few days before the funeral, on a horoscopically suitable date, the bereaved family hires a group of Buddhist nuns and monks to recite sutras for the spirit's well-being. These religious specialists, who live in temple convents or monasteries, arrive with a marquee and much ritual equipment, rented as part of the package. The marquee is raised, usually on the sidewalk and street in front of the house, and the monks and nuns busy themselves with reciting the number and kind of scriptural chants for which 
they have been paid. Sometimes Daoist ritual specialists are hired as well. One or another of these specialists usually hangs up gruesome paintings of the fearsome torments that souls being judged in the next world may undergo-being ground between millstones, sawed in half, or, for women, raped by animals.

On the day of the funeral itself, guests gather to pay their last respects to a small paper image or a large funeral portrait of the dead person on the temporary altar in the marquee. An arriving guest goes first to the record keeper, generally a friend of the family or distant relative, who lists the guest's name and condolence gift. This is usually money - at least enough to cover the cost of the feast the guest will later consume-in a white envelope. Sometimes the presents are dress lengths of cloth or, from important men who are invited to more funerals than they can attend, a white cloth banner with an appropriate message of respect for the dead and the giver's signature. These are hung throughout the marquee, evidence of the family's respectability and connections. The guests file slowly up to the altar, fold their hands in prayer, and bow deeply three times. Often, a dish of fragrant sandalwood powder stands by a little charcoal brazier, inviting each guest to burn a pinch-a means of warding off the contamination of death. As guests mill about, talking in subdued tones, the funeral musicians and trucks for the processions arrive. Some families hire out-of-work opera actors to appear in the costumes of Buddhist fables to accompany the procession. These brightly made-up street toughs drift around, waiting for the simple food the procession workers will receive before the coffin is taken away.

After all the guests and relatives have paid their respects, the coffin is given its final "closing" nails. Women in their childbearing years retreat into the houses at this powerful moment for fear of injuring their fertility. At this time, a father will beat the coffin of a son who has unfilially preceded him in death. Laborers hired for the day's heavy work heave the large, ornate coffin onto a truck decorated with white paper flowers, and the funeral procession of bands, loudspeaker vans full of chanting nuns, costumed figures, and jeeps or taxis carrying wreaths moves off toward a mountainside cemetery. The major mourners follow on foot for a few blocks, before climbing into the vehicles for a speedier trip. At the graveside, workers lower the coffin ceremoniously amid the relatives' loud weeping. The family makes offerings of incense and paper spirit money before hastening back for the funeral feast.

Late in the evening of the funeral, the family gathers to perform the rituals that will lead the new spirit into the other world and provide it with the money and clothing it will need there. Old-fashioned families hire 


\section{Chinese Working-Class Lives}

Daoists to perform acrobatic juggling acts with flaming torches to "entertain" the spirit one last time before it enters the hell of judgment. After this is done, the Daoists instruct the family to bring out several large cooking woks and fill them with a sum of folded spirit money, calculated on the basis of the person's birthdate. Some of this money will pay the deceased's mystical debts in the other world, freeing his spirit to be reincarnated after undergoing punishment in hell for his misdeeds. The spirit can use the rest of the money to buy what he needs, and, it is hoped, to bribe himself free of punishment (Gates, 1987).

As the money burns, the Daoists lead the mourners in a circle around the fire. The chief mourner carries the dead person's paper image, while another may carry the paper image of a wife who died before her husband, so that the two spirits may travel together. Others carry incense pots or bamboo branches that attract spirits. The long, imaginary journey to the dark and dangerous other world ends when the great heaps of spirit money finally burn down-the new spirit has "crossed the bridge" into hell. Finally, for his use in hell, the family brings out a colorful, completely furnished paper house, sometimes six feet high and costing two months' wages, installs the paper figure of the dead, and sets it all alight. For a moment, light glows out the windows, revealing paper pictures on the walls, a television set, and elegant furniture. Then, in a burst of flames, it is gone-transformed by fire into a real house in another world-a sad and lovely ending to a life.

The family will ask a Daoist to inscribe the dead person's name on a wooden tablet on the family altar. In a careful household, it will also write the name on a slip of paper pasted inconspicuously on the altar table with the names and death dates of all recent ancestors. The family will celebrate these death days yearly for generations to come, and someone will pray daily before the ancestral tablets. The real effect of all these rituals is, of course, on the living, who through their performance are taught the significance of the family, a respect for its continuity and the subordination of individuals to it.

We have seen that in Taiwan's working class there is a close connection between a family and its members' work lives. Do people make decisions about their occupations in order to keep their families together-as most Chinese would surely insist-or do they shape their families to fit their available (and prospective) resources? The first option seems the obvious choice. Throughout the life histories, we see parents using the labor, skills, talents, and property of the whole family for the maintenance and betterment of a unified family household. Families do divide, usually at times of 


\section{Home and Family}

marriage or death, but occupational plans are frequently made which will enable a household to expand by adding or retaining members. People choose occupations to realize the patrilineal coresident family whose image is the culture's ideal.

But the view that resources shape families is also tenable and may have been even more pertinent in the recent past. Families that own incomeproducing property such as farms and small businesses also need human labor if they are to support themselves from that property. Chinese farmers have always been acutely aware of the need for enough labor, especially male labor, to till their fields without recourse to hiring workers. Carpenters, miners, tailors, and many others often prefer to work in teams of two or several men, ideally a father and his sons, and some of the homemaking, artisan, and shopkeeping activities of women are more efficient, too, if a mother-in-law and daughter-in-law or daughter can take turns or assist each other. Under some circumstances, especially in the years since 1960 , children who could not be usefully employed at home could easily find work elsewhere, so family labor resources could be allowed to outstrip family labor requirements in following the patrilineal ideal. In the past, when such work was not so available, children were more frequently sold, adopted, or married out, often shortly after birth.

But even the family ideal has changed over time: now, daughters should work and may choose their own husbands; divorce is thinkable, if still a tragedy; a few well-educated children moving into the white-collar world may represent a better family investment than a lot of sons doing manual labor. More than ever, a complex calculus among factors of capital and labor, and economic necessity and desire to approximate kinship ideals governs the composition of families, the success of businesses, and the evolving shape of the working class.

Mrs. and Mr. Zhang, introduced in the next section, tried hard to model their family after the ideal, although they realize that in modern times the ideal has changed. Because they themselves chose their marriage partner, they do not expect to choose their sons' wives, though they are not sparing of their opinions on the subject. Because they left their parents behind on the Mainland and have thus done nothing to fulfill their filial duty of support, they expect only limited aid from their sons in the future. The external circumstances of the Nationalist retreat to Taiwan have left them with an atypically minimal family, while the expanding economy has given their sons room to maneuver economically in ways that move them away from the kinship ideal. The Zhang family shows clearly the changes that, often more subtly, continue to reshape Chinese families in Taiwan. 


\section{Chinese Working-Class Lives}

\section{Zhang Xiuzhen: Immigrant Cook}

Like many of her fellow post-1949 migrants to Taiwan, Mrs. Zhang has always expected that she and her family would one day return to the Mainland-by choice, to the northern home in Shandong province where she was born over fifty years ago. Living with other Mainlanders in military enclaves, she has not bothered to learn the Taiwanese language and still finds the southern climate and surroundings alien. She is uneasy at the way her sons have adapted themselves to local life, and at the way that life has drawn them away from the tightly ordered family created for them through much sacrifice. Like many Mainlanders, she believes that if only she and her husband had been able to return to the Mainland under a triumphant Nationalist government, their loyalty would have been rewarded by high position, and her sons would have remained filial, as she remembers men to be "back home."

But Mrs. Zhang is practical. She has worked hard as a servant and plans to take advantage of the expanding economy of the 1980s while she has her good health. Her life shows us something of the advantages and the disadvantages of being a small part of the state-employed sector in Taiwan, and of the determination with which Chinese parents pursue traditional goals for their families.

Zhang Xiuzhen's vitality lights up her plain, round face. Her dark eyes snap and sparkle as she talks, and she talks a great deal. Plain-spoken, in the tradition of her earthy, downright Shandong forebears, she always has her say. Entering her fifties has not slowed her down, nor has her appearance changed much in the last twenty years. Only a little gray shows in the thick black hair she wears cropped near her head. It is hard to recognize on this broad, unlined brown face the pale, fragile-looking features of the seventeen-year old bride in her wedding picture.

Her liveliness of speech is broken, sometimes, by an almost-conquered stutter that seems to result from an excess of energy that is unable to escape through mere words. Mrs. Zhang has worked hard all her adult life, and by nature remains in motion. She knits-sweaters for friends and relatives, warm bed socks for herself, toys as gifts for children-or sews-traditional handmade Chinese rag dolls, curtains, clothing. Wherever she is, she dusts, cleans, airs, scrubs, scalds, whitens-always efficiently and with good cheer.

Her real vocation, though, is cooking. In a society where food preparation is a grand art and discriminating eating is a sign of personal cultivation, Mrs. Zhang's food is adjudged superb: northern dishes from her own background, southern-style learned from her Guangxi husband, Cantonese 
and Sichuanese food from and for old friends from these provinces, apple pie and turkey with sage and onion stuffing learned to please American visitors-all are perfect of their kind. Pickles? Pickles indeed. She is constantly making them, drawing on peasant food preservation methods from all over China, preferring, herself, the fiery, sour, fermented cabbage of Sichuan. "Once you get a crock of that started, you can keep the liquid going for years," she told me, and she was right. Steamed breads, dumplings, homemade noodles? There is always dough being kneaded or slapped or rolled out in her kitchen. A trip with her to one of Taibei's big city markets is an education in the art of purchasing the absolute best for the absolute least.

With these skills, Mrs. Zhang has earned money for her children's education and supplemented her ailing husband's small income. Her abilities have given her the chance to see much more of life than she would have had she remained just a housewife in a rural military town. In 1982 her talent brought her to the United States for a year, a pleasure that proved to be greater in the anticipation than in the reality. She is proud of these accomplishments, but their costs have been high. For twenty years, she has lived in other people's houses, often able to return to her own only once every two months.

In one of these employers' homes she paused long enough to give me this account of her life. It was one of her better jobs-cooking only, no housework-for a rich military family from her own province. Like all the houses in which she has worked, the contrast with her own is great. The general's house and garden might be anywhere in southern California, despite its large domestic staff and numerous Chinese art objects. It contains imported American furniture, appliances, plumbing and security systems, space and luxury within; fresh air, tranquil suburban sounds and privacy without. It is as different as possible from the crowded, noisy, and often malodorous military village where the Zhangs live.

These residences are not home. She is a servant in them, no matter how kindly she is treated. But they are comfortable and interesting. She sees, hears, tastes, and experiences things "outside" that she never would have had she stayed at home. Her shuttling back and forth was at first suffered only for the children's sake; later she grew to like the comforts and the stimulation. But the gains from this life, though real enough, conform to no cultural pattern of aspirations. They are pleasant, but ephemeral and frivolous. What she believes she has lost-a strong, responsible, and supportive family - is the classic Chinese goal. When she weighs her life, as she often does in brief allusions or through comments on the lives of others, the failures seem clear-cut, the achievements blurry. Perhaps her American 
adventure will shift the emphasis somewhat. Her plans for the future hint of this.

Ren qing, "human feelings" or "human-heartedness," is a Chinese ideal that requires that people recognize and act on each other's essential humanity, regardless of externals. The flavor of Mrs. Zhang's ren qing influences all her dealings with people and, on one occasion at least, with other creatures as well. Although my voracious, flea-ridden cat was the bane of her frugal and cleanly existence while she lived in our house, the morning the cat had kittens found Mrs. Zhang busy preparing chicken and ginger soup—the traditional Chinese broth for new mothers.

My ancestors are from a village in Shandong province in Yantai City, but I was born in 1930 in Qingdao City, where father worked as a builder. I had an older brother, an older sister, a younger sister, and a younger brother. Mother was a beautiful woman, very capable and very strict with us children. She was well educated, too. My older sister was very like hertaller and fairer-skinned than I, and both docile and good at her studies. Mother's brothers disciplined my older brother in the old-fashioned way. They'd slap his face if they caught him outside the house smoking or looking untidy. My mother's family was very well organized and upright.

Father was not that way. He drank a lot and did not have a strong character, so we lived with Mother's brothers in Qingdao, with occasional visits to Father's village home.

I took care of my little sister and brother more than anyone else because Older Sister only like to study and didn't like to look after them. Playing, I sometimes lost my little sister, who was only three years younger, so I was scolded a lot. By the time my little brother was born, I understood things better and took good care of him. Once, when I was ten, Little Brother had some kind of infection and couldn't urinate properly, but neither Mother nor Older Sister seemed to pay much attention. I walked a very long way to pick some leaves to make a tea to cure him-I had learned some medicine from Mother. Nobody told me to go, I just decided to do it.

I went to school for about six years-one or two at Protestant missionary schools, the rest of the time at Chinese schools. I didn't like it much. The rooms were cold, the lessons dull, and my mother didn't tell me I had to go, so I skipped a lot.

When I was nearly twelve, Father became ill. We went home to his village to wait for him to die, living there for about a year. In Father's village, my father's sister told me many things about country life that I did not know. She was a very devout Buddhist and liked to go on pilgrimages. Lao Shan, the mountain with the famous mineral-water springs and tem- 
ples, was a few days' walk away. She would have taken me there, but because I had not completed my twelfth year, she was afraid that the gods would covet or injure me. One of the things I remember about her descriptions of the temple there was that a famous goddess was worshipped there who helped women bear children. A woman who wanted a child came to the temple and prayed. The temple keepers gave her medicine to eat, incense ash to carry home, and a small image of a baby boy or girl made of earth to take away with her. These earth babies were to be buried in the thick adobe house wall over the earthen sleeping platform, sealed in. You could paste a picture over it so no one would know it was there. After you had a child, you made a pilgrimage to return the earth baby, and made a thank-offering of oil or money to the goddess. My aunt knew a lot of things like that, so I learned something about country life.

I also remember that while we were living there my younger sister and I decided we wanted to have our feet bound. Auntie helped us to do it. Oh! Did that hurt! We tried for two days, and then we were glad to give up that foolish idea.

My sister was seventeen, and very pretty, so she was asked for in marriage by the son of a rich landlord, the local baozbang. ${ }^{2}$ The parents talked it over and agreed to something very modern: they allowed the young couple to meet at our house to have a look at each other. It was very embarrassing for both of them, because young people were very innocent in those days. "His eyes are too small," my sister said, but she didn't seem to really object to him, so they were married in the country fashion, with the bride carried to the groom's house in a closed sedan chair followed by the groom in another. This was before my father died.

The family she married was rural and old-fashioned, but at least they were rich. They owned a lot of land, had many tenants, lived in a big courtyard-style house with many rooms, and kept cattle, horses, and donkeys. Also, there was no mother-in-law, and only one unmarried sisterin-law was still at home. Her father-in-law and husband's brother's family were good to her. She seemed happy, and in a year had a little boy.

A year later, in 1947, the Communists came, and killed her husband because of the family's wealth and Nationalist connections. The older brother was killed too, and the old man was paraded before the villagers to punish and humiliate him.

One night, Sister heard someone on the roof, spying on the family-a Communist agent. But he was also an old family friend, who had not known who she was. When he found out she was to be arrested, he came secretly

2. A low-level Nationalist official. 


\section{Chinese Working-Class Lives}

at night to escort her and the baby on a six-hour walk to the nearest railway, from which she returned to us in Qingdao.

Mother urged her to remarry for safety's sake, although normally a widow should wait three years to mourn her husband. Since all his family was dead and their name was dangerous, my sister married. Later, she became pregnant again, and was unlucky enough to be giving birth when her husband was sent to Taiwan in 1949. The second husband sent someone to get her, but the messenger could not find her because she had come to Mother's to have the baby. She is still there, as far as I know. I sometimes hear from her husband here in Taiwan; he married a Taiwanese woman after it became clear that we could not go home to Shandong.

We had stayed in the village for a year after Father's death, but returned after that to the city because Mother couldn't get used to country life. My father's brother farmed our village land, and every year sent half the proceeds to us, which we lived on. Two or three years later I decided to go to work in a clothing factory. My girlfriends were going, and I thought it would be fun, though we didn't really need the money. They paid very little, and it wasn't fun at all. I couldn't stand it after the first day, so I quit.

In about 1947, young men from an air force regiment from the south just then stationed in Qingdao began to meet sweethearts. My girlfriend's future husband brought Zhang Zhengming for me to meet, thinking he needed a wife. He was twelve years older than I-I was seventeen thenand he was around thirty, so I felt very shy of him, considering him just another boring adult. He wasn't especially handsome, either, because his teeth stuck out so.

He began to come to our house to chat with the older people and occasionally to take me and my younger sister and brother to the movies. After a couple of months, he began to ask me if I liked him, and he spoke to my mother about our marrying. Mother asked me if I wanted to marry him. I was too embarrassed to say half a sentence! "Whatever you want me to do is all right with me. It's not my concern!" I answered. My girlfriend, already married, said that marriage was fun, because I could have my own house and no one would order me around. So I agreed.

Mother liked my husband and thought it was a good thing for me to be married to someone with his kind of special training. It was awkward arranging the marriage because he had no relatives in Qingdao to do things for him. Mother treated him like a son, ${ }^{3}$ and made a wedding feast for us. She sent cakes to our relatives to announce the wedding and helped us find

3. That is, took on the financial responsibilities appropriate for a son's wedding. 
a small house to live in near home. I wore a Western-style white wedding dress, like the women in the American movies.

When I was married, I was seventeen by our count, sixteen by Western reckoning. ${ }^{4}$ I was really a child, knowing absolutely nothing about adult things. And of course, I was completely innocent about the relations between men and women. I couldn't cook, so every day I'd go home while my husband was at work and eat my mother's food. He would come to fetch me, and we would all eat there. He could cook, because of his early life as a peddler and because you have to take care of yourself in the service. Sometimes he would cook for me. But often he went out to drink and gamble with his air force buddies, leaving me alone, so naturally I often went home to Mother.

After a year of marriage, when I was pregnant, the order came to fly to Taiwan. Mechanics like my husband and his friends could take their wives because we had lots of airplanes. There were so many rumors then.

My family was afraid Mr. Zhang would simply go and abandon me. I was furious that they had not warned me of this before the marriage! They wondered if he had another wife who would be taken instead of me, and I was more and more miserable. Also, I had a lot of morning sickness at that time. When the time came, though, he got me on a plane to Nanjing with a lot of other Qingdao girls, and from there we went to Taiwan.

Everyone said we would be back soon. How were we to guess we would stay so long? Several of my girlfriends were going, and one unmarried girlfriend came to say good-bye at the airport. We all coaxed her, "You come too, to Taiwan. It will be fun, and we will come home soon and go to apologize to your mother for going without permission." She came with us, without saying good-bye. None of us have ever seen our parents or heard from them again. I don't know if my mother is alive or dead, though I suppose she must be dead by now. It's been so many years.

When we arrived in Taiwan, we were stationed in Taoyuan. At first we slept in temples, and they cooked rice in a big pot for all the dependents. It was crowded and frightening, but we helped each other. Our husbands got paid most of the time but everything was very expensive and hard to buy. After half a year, we moved to another post, where we stayed for about three years in married barracks.

Just after we moved, I had my oldest son, Bright Reputation. A year

4. Chinese people count every calendar year in which they have lived. A baby born one day before new year's counts as one sui, and the next day, in the new year, becomes two sui old. 
later, I had a daughter, who lived only fifteen days. The older child injured the baby while playing, and she died. I often wish now I had a daughter; they are closer to their mothers than sons. A year later I had another boy, Bright Light.

Two years later, in 1954, my husband was transferred to where we live now in the south. It was really a little country town then. The air force built housing that we were later allowed to buy, where my family and many others from that group still live. The houses were quite small at first: two rooms about three meters by three meters each. We cooked outside and used public toilets at the end of each row of houses. Each house had a small front yard, the same size as the house, so we have built another room on the front and a kitchen on the back. Some people make a flower garden in their yard. We still use the public toilets, the biggest shortcoming of our housing. Some people are not very clean.

After we settled there, I had my sons Bright Virtue and Bright Nation. We were going to call the fourth son a more refined name, but my illiterate old man got it mixed up, and the registry official put down "Nation" because it sounds so patriotic. In those years, I just bore children and took care of them. It was very hard, but sometimes it was fun. There was so much to do to take care of them, and I was young. I had no mother or mother-in-law to help me or tell me what to do. It was hard to get good food and medicine, too.

The fourth boy was very sick when he was small, sick for more than a year. He had a terrible ear infection-his ears ran and he cried all the time. I was afraid he would be deafened. Because he had fever, I fed him only rice gruel for a long time, so as not to cause more heating of his body's humors. He cried for food, but I would only let him eat gruel. That year his hair fell out and got a reddish color and his stomach swelled. I thought he would die and kept trying to get medicine for him. The military hospital would treat him after a long wait, but it didn't help. Finally, I borrowed money and went to a private doctor. He gave him pencillin and the ear infection cleared up. Medical care was very hard to get for us lower-level military people then.

At about that time, I became a Catholic. I had heard about Catholic missionaries in Shandong who gave free food to poor people and helped them with medicine, so I was not surprised when I saw nuns in their black clothes. Some nuns began to come to our married barracks to preach their faith. They spoke about doing good, not doing evil, and abandoning superstition, saying it was not necessary to believe in gods and spirits. They came often, and some of us younger women brought our stools and listened to them. After a while, they gave us an examination. Those who passed could 
be baptized and enter the church. I went to church fairly often, when I had time, bringing the little boys sometimes. The Catholics did many good deeds in those days, giving powdered milk and medicine free to people who needed it. They often helped me out.

When my first boys began to attend elementary school, the teaching was very poor. I knew they would need a lot of help, but we couldn't pay to send them to cram school. So I decided to learn to read again to help them. We studied their lessons together, and I made them do all their homework. That's how I really learned to read.

When my biggest passed the examination to enter junior middle school, Old Four ${ }^{5}$ began primary school. Junior middle school required school fees in those days, and all the boys needed uniforms and supplies for school. We didn't have the money for all that, so I had to go to work outside our home. For a while, I bought vegetables from the wholesale market to resell in our neighborhood, but the profits were too small. Taiwanese farm women could always undersell me, which meant that sometimes I lost money.

However, because by now my husband had taught me to cook, I began to go into other people's houses to earn money. At first, I found a job with a Chinese professor's family in Taibei. Later, I began to work for American graduate students. I am a Shandong person, very outspoken, like you Americans, and I speak the national language with a standard accent, and only a little bit of a Shandong accent. American students liked that and they liked my cooking. I worked for a different student couple every year after that until 1974. Then the students stopped hiring people, because our wages in Taiwan were getting bigger as their scholarships were getting smaller. Working for them was interesting. They were learning Chinese, so we could have fun talking. They were more democratic than Chinese people, so when I spoke my mind, they were not angry.

Living away from home was really worrying for me, though. The boys were growing up, and I could only come home once in every month or two. My husband was away working during the day, and he didn't supervise their studies at night because he can't read. Also, my working away from home caused gossip. Other children sometimes said bad things about me, so my sons would fight them. It was very bad for them to have such rough habits.

My wages were no more than NT $\$ 1,000$ each month. Of course, I ate my employers' food. So sometimes, even though I worked, there was not enough money for school fees. Sometimes I had to borrow from my employers, sometimes I formed a rotating credit club with my friends. We kept

5. Children in Chinese families are often referred to by the number of their birth order. 
them in school, telling them it was important for the family's future that they study. In spite of all that, not one was a good student. Not one graduated from a good senior middle school. The oldest did his military service for three years, then became a laborer.

The second joined the air force to become a mechanic. Because he really knew how to talk, people liked him. He had a lot of Taiwanese friends, spoke Taiwanese, and wanted to marry a Taiwanese girl. Then he died. While he was repairing a jet engine, the pilot started the plane. He was crushed. That was in 1975 . The country gave us NT $\$ 300,000$ (U.S. $\$ 7,500$ ) in compensation when he died, and NT $\$ 130,000$ (U.S. $\$ 3,250$ ) every year for ten years afterward. The country was going to bury him in a small military cemetery, but his father said he had died for his country and should be buried in the national heroes' cemetery. He and my oldest son went again and again to argue for this. Finally, the authorities permitted it. Now his grave is with all the other air force heroes who have died in Taiwan for their country. Every year there is a big ceremony, with high dignitaries to honor them.

My son died only a few weeks after he had become engaged to a very nice Taiwanese girl. She had loved him for a long time, and really suffered sometimes from his bad behavior. She was very loyal. After he died, I treated her as a daughter. When she finally married, five years later, I went to her wedding and quietly gave her NT $\$ 500,000$ (U.S.\$12,500). This was just for her; her husband's family didn't need to know about our real relationship. Now she has two children and I think she is happy.

My third son was too stupid to finish school. He had a tumor on his vocal chords while he was in high school and needed an operation. We had to take him to the air force hospital to be treated, which really worried me in case they cut him carelessly and he became a mute. Fortunately, that didn't happen. After serving in the army, he went to Taipei to work in a restaurant. He has a girlfriend, one of the mountain Aborigine women, but won't get married. I hardly ever see him.

Number Four was always a happy, joking boy. I feel I was unfair to him more than all the others because I left home to work when he was so young. He did pretty well in school, served three years in the army, and took lessons to learn to drive a truck. Now he is married and lives near us. I told him not to get married-his eldest brother's marriage should have been an example to him-but he got married anyway. We had to help him. Now I tell them to wait to have children. After they earn some money they can still have them.

My oldest son was married in 1975 to a very pretty Taiwanese girl from a big family near a fishing town in the south. I rented a small bus to drive me 


\section{Home and Family}

and about ten friends to go to their house for the engagement, so I met the people in her family and saw how they lived. They are country people, with customs different from ours. Neither I nor any of our friends could speak Taiwanese to them, and only the children could speak Mandarin to us. I can say one or two things in Taiwanese, but mostly we talked to ourselves and they talked to themselves at the engagement party. They served us a big meal-they had invited more than twelve tables of guests, close to two hundred people-including the raw fish that Japanese people eat. $\mathrm{My}$ daughter-in-law's father had bicycled into town at four o'clock in the morning for the fish, so it was very fresh. But we mainland people don't eat such things. The father and mother announced the engagement to Heaven and Earth and their ancestors, and my son gave my daughter-in-law an engagement ring. We gave them NT $\$ 40,000$ (U.S. $\$ 1,000$ ) as a bride-price, and her mother gave it all back except a few thousand. I was glad of that, because it showed they were not the kind of family that sells their daughters, like some Taiwanese. We took a lot of photographs of the two families, and then we went home, taking our guests to a few scenic spots on the way home. It seemed like a good beginning for my son's marriage.

A few months later, it was our turn to take responsibility. We held the wedding feast in a restaurant in our town. A few people, including her parents, came from her side, but mostly the guests were our friends. We invited four tables. It was quite simple, really. The new bride was not coming to live with us, so there were no gifts coming to our house. Each guest gave one or two hundred New Taiwan dollars (U.S.\$2.50-\$5.00) in a red envelope at the dinner, which paid for the food and liquor.

The new couple went to live near my son's work in Gaoxiong, where my daughter-in-law found work as a hostess in a restaurant, because she is so pretty. We hoped they would work for a while and save money, but no. They had three children-a boy, a girl, and a boy-one after another. I kept telling them to stop, and finally my son had an operation so they wouldn't have any more.

In the early years of their marriage, I went back to work to help them out with money. I found a job with an American missionary family, working for them about two years.

After two years, I got very tired and upset because of my eldest son's marriage troubles, so I went home to rest for a few months. The missionary family was a good family, but they didn't understand our Chinese ways very well. They understood how to give orders, but not how to show real humanity. Anyway, I needed to help my son and my daughter-in-law run their family better. They had three children so quickly, even though I told them to wait. Then they didn't want to work hard to support them, 


\section{Chinese Working-Class Lives}

especially my daughter-in-law. She only wanted to wear pretty clothes and go out to be entertained every night. My son, who gets dirty from manual work, wasn't good enough for her any more. She didn't seem to care about the children. Sometimes she left them in the country with her parents for a long time where they got sick, and their legs were all scabby from mosquito bites. For a while I tried to tell them how to behave properly, so they could establish their family solidly.

Because everything costs money, after a while I looked for work again. A friend told me that a high air force officer from my home province wanted someone to cook for his household, someone who could cook the wheatbased foods we Shandong people like. I went to see them and saw they were a very rich family. There was only the general, his wife, and his old mother at home. They had a gardener and a Taiwanese woman to clean the house, do the wash, and wash the dishes, so all I had to do was shop for food and cook. They lived in a pleasant, mountainside suburb with fresh air and good surroundings. So I decided to stay. That is when I took up jogging. They paid me not too much in salary, but they gave me presents, and when guests came they left very large tips for my cooking. When their old mother died after a year or two, the family gave me a large gold ring in her memory, for helping nurse her at the end. In this way, they behaved toward me in the old-fashioned Chinese way. My position in the house was so good that the Taiwanese help were jealous-the only bad thing about the job. I cooked for them for three years.

During that time, my son's marriage broke up and he and his wife got divorced. That was a terrible time. I was furious, and sometimes I thought I would just go to the sea and throw myself in. Oh, I was angry! I told them what they had to do, but they wouldn't do it. I gave them money. I brought them to live in a little house just across from us, where my husband could look after the children and cook for them while our daughter-in-law worked. We treated her like an empress, with her father-in-law waiting on her, and me working to support her children! Oh, I was angry! But there was nothing for it-they divorced. She took the two older children and left the youngest for my husband to care for. My son moved back to Gaoxiong, where he seems to drink up all his money. I hardly hear from him, and don't want to. The little boy is company for my husband, who is very good to him. The mother will want him when he is older though. It's right for the brothers and sister to grow up together, and to be with their mother. My husband has old-fashioned Chinese ideas, and thinks we should keep the children, or at least one of the boys, because they bear our name, and because his son will not be able to have any more children. What can you do with a situation like that?

After they were divorced, I thought I could teach my eldest son a [128] 
business so he could stop being a laborer and have a better life. I quit my cooking job and went home to make and sell meat dumplings and little meat-stuffed buns. I am a good cook, if I do say so myself. Besides, in Taiwan now anyone can make money selling food. So many people are working, so they have money and don't want to cook. We freeze dumplings-I can make three hundred a day by myself-that they can take home and boil or steam themselves. It's very convenient, so many people come to buy them. At first, we didn't know how much to charge. Others who sell meat buns told us we were selling too cheaply. We thought if half our selling price was profit, that was fine. But three-fifths of the selling price should be profit. After all, we work all day, almost every day, and don't count the cost of our labor. If we had to pay anyone to do it, there'd be very little left.

It's not easy to calculate all the costs, either. We learned some tips from an old friend who makes buns in Taibei. He advised us to sell by weight, not by number. When you sell by number, it makes it hard to tell how much the cost is. We got a scale, and sold by weight, we raised our prices a little, and soon we were grossing NT $\$ 15,000$ (U.S.\$375) a week. So the money wasn't bad. We really worked, though.

I took some savings, rented an empty house near ours, bought some second-hand chairs and tables, and opened a restaurant. I tried to teach my son how to choose the best meat and vegetables, how to make dumplings, and how to treat customers. My husband helped a little, but his manner is very rough. When you run a restaurant, you have to talk nicely to customers and treat them right. My husband just says, "Take it or leave it," and walks away. He's no help. My son is too much like his father. Besides, he doesn't want to learn anything from me. He worked for a few months, then said he wouldn't work any more. When he left town, my blood pressure was so high I nearly died from anger.

My fourth son married a little while after that. He and his wife were having a hard time making ends meet, so I asked that son to help me sell dumplings and buns. I found them a very cheap rental near us, moved them down there, and started to teach him the business. Things went all right for a while, till they decided to take over themselves. I told my son that I had had an offer of NT\$25,000 (U.S.\$625) for the furniture and equipment. They could give me NT $\$ 15,000$ (U.S. $\$ 375$ ) for it over time, out of their earnings. They talked about it, and told me they thought that was too much, that I was trying to make money off them! I nearly died of anger. My husband I are getting old and I am still working to help these sons. I need my money for my old age - these sons don't give me anything! How can I afford to give them everything? I told them I wouldn't sell the things to them. They will have to look after themselves.

My son got back his old job driving a truck, but they still live nearby. 


\section{Chinese Working-Class Lives}

They come over all the time to ask my husband to cook for them, and he does. I tell him they need to learn to be independent, but I know he doesn't listen when I'm not there. He feeds them anyway.

All this really made me angry for a long time. As luck would have it, the general's family contacted me about then, wanting me to work for them again. Their daughter in America needed someone to help with her new baby, so they wanted to send me to her for a year. The general would pay for my travel there and back, and for a visit to Taiwan after six months. His daughter would pay me U.S. $\$ 300$ each month, as well as my food and housing in their house. I was glad to get away from all the family troubles, and I have always wanted to travel. I said I would go.

I'm glad I went. It was interesting to see how Americans live in their own country. I have known a lot of Americans, and understand some of their customs, but to see them in their own country is different. There are both good people and bad people there, just like in Taiwan. I could have stayed, for the general's family could have helped me emigrate, but decided not to. I was really lonely there, with no one to talk to. Getting used to the food was really hard, for while some American food is good, to my taste a lot of it is bland and uninteresting. There are too many frightening and unfamiliar things in your country, and it's not safe to walk alone in cities there. Being away gave me time to think about my and my husband's future, though.

What I think is this. We live in different times now. It is useless to try to have an old-fashioned Chinese family passed on from generation to generation. Even I didn't take care of my parents and parents-in-law, because my husband and I came to Taiwan. How, then, can I expect our sons to care for us? I don't want to use up all my money on them and then, when I am old, have to go begging to this one and that one for food. Two of my women friends and I are going to reopen the restaurant, work hard, and make lots of money. I'm going to save everything I can from that and from my husband's pension.

He gets NT $\$ 60,000$ (U.S. $\$ 1,500$ ) each year now. His pension was raised recently because of the rising cost of living. We get rations of oil, salt, fuel, and rice which are more than we need, so we sell some. But it is not much these days. My husband is too old, his health is too bad, and he is too illiterate to find work, especially in our town where most businesses are Taiwanese. My sons give me nothing. I have to work to earn money.

If I can save NT $\$ 100,000$ (U.S. $\$ 2,500$ ) more for each of us, we can buy places in an old folks' home where they will provide food and medical care for the rest of our lives. That's the way society is now, and that's what I'm going to do!

My, my, life is very complicated. We taste the sweet, the sour, the 
pungent, and the bitter in our lives. Sometimes when I think about how hard life is, I cry, but then, when old friends get together, I feel warm and happy. We just do the best we can.

\section{Zhang Zhengming: Air Force Loyalist}

Zhang Zhengming, Zhang Xiuzhen's husband, is a retired air force mechanic from south China. Now in his late sixties, he has served the Nationalist military since his youth and cannot even imagine another system of government or a Chinese who would want one. Anyone lacking in his kind of affectionate loyalty, he thinks, must be either wicked or absurdly ignorant. He points out that there are flaws in the operation of the sociopolitical system under which he has lived his life comfortably. Nothing is perfect. But with better education, the right men in charge--society would operate as well as anyone could wish. There are many men like Mr. Zhang who credit their rise from rural hardship to a modern occupation in a prosperous country to Jiang Jieshi and the Nationalists. What Mr. Zhang cannot understand is how, after all the social betterment he has seen during his life, young people can have degenerated so quickly. He represents a segment of Taiwan's population-Mainlander career enlisted servicemenwho have not needed a place in the rapidly industrializing economy, and who cannot understand the difficulty their children are having in finding theirs.

Zhang Zhengming and I talked about his life through several long afternoons at his home of twenty years, part of a large complex of quarters for married military in southern Taiwan. The house shares walls with neighbors on each side, and more neighbors live across the 5 -foot alley that passes the front gate. In winter this sunny corridor serves as a meeting place for little knots of knitting women and card-playing men, seated on the tiniest of stools, chatting in dialects from everywhere in China. In summer the trees that families have planted in their yards help cool the breezes that pass from door to door, carrying the smells of cooking, of carefully tended flowers, of the community toilet at the end of the row.

Mr. Zhang lives now, as he has throughout his life, in unavoidable intimacy with many other people. Two doors away, a family struggles with the burden of a senile old mother who, having gone blind, cannot tell night from day and loudly demands meals at inconvenient hours. Family rows erupt occasionally; everyone's taste in television and radio programming is as public as their normally loud-voiced conversations. 
His ties to many of these families come from the shared past, when the men traveled together on the China mainland, fighting the Nationalists' wars. They know each other well, though intimacy does not necessarily mean liking. Some people pass in the narrow alley, or at the nearby vegetable market, with the curtest of nods or with no greeting at all. The burden of a life lived so publicly is an accustomed one, but Mr. Zhang feels it as a burden nonetheless.

Mr. Zhang, perhaps more than most, finds his position an ambiguous one in the world and in his family. While Taiwan enjoys unprecedented prosperity and the changes of affluence come ever quicker, his life, his possessions, his salary, and his opportunities remain the same. With his wife working away from home to support the family, he, in poor health, remains behind to cook and care for children. He had four sons, an accomplishment many Chinese would envy, but his sons live apart from him and do nothing to lighten his old age.

It should surprise no one, then, that Mr. Zhang is often grumpy and does not take neighborly needling well. What stands out, though, is his gentleness in the care of his small grandson, the shining neatness of the house, the soldierly pride in his appearance. A short, slight man, he carries himself with dignity, eyebrows shooting out like a Chinese opera hero's over round, alert eyes. A set of ill-fitting false teeth makes his heavy provincial accent hard to follow, but he talks with verve and much gesticulation. Initially uncomfortable about the interview, he quickly relaxed, expanding enthusiastically on his earlier life, when as a young man he was one of Republican China's few modern warriors in one of this century's great conflicts.

I was born in Guangxi Province in 1922, near the Guangdong border, at a time when "the area of the two Guangs" was not yet controlled by the central government; each province was independent then. The Cantonese ${ }^{6}$ are very regional-minded. Even now, when two of them are together they will speak their own language regardless of whether others can understand or not. I learned to speak Cantonese as well as my native Guangxi dialect while I was growing up in that area, learning our national language only when I entered the service. I grew up among many relatives, but my own father, mother, and brothers died when I was seven. My elder male cousin had married early at nineteen, but after many years his wife had no child. This made all the relatives angry, so in his forties he married a second wife. She had no children either. Our lives are determined by Heaven. We only

6. People from Guangdong province. 
receive what we are given. This aunt raised me and my two sisters as adopted children, and was kind to me. I lived with them until I was seventeen.

Our lineage had three divisions: one, that of my cousin and his four brothers, had only two sons in the next generation; the second, where the only son died, had three daughters; and the third, through my father and me, is now here. I had four sons, three of them living, and my first son has two sons, so I can say that I have continued our family as well as anyone. Many of my older relatives back home must be dead now. Even my sisters, who were in their twenties when I was in my teens, must be old by now.

Where I grew up, most men farmed, if they had land, or carried goods from place to place as porters, or they operated some business. Before I left home, I helped my cousin peddle goods to the mountain villages. Guangxi is mountainous-real mountains, big, blue-green, with no grass on them, and lakes here and there. Many have big natural caves that the Communist bandits used as hideouts, living for decades and never getting caught. They could always retreat deeper into the mountains and find food there, though people who didn't know the mountains could easily get lost in them. I've walked up and down those mountains many times, going from my village to Liuzhou City and back. Also in the mountains, lived many Zhuang and $\mathrm{Miao}^{7}$ people. Their clothes, languages, and customs are all different from each other and from ours. Sometimes the language changes from village to village. In the course of doing this kind of business, I learned Cantonese, which is how we communicated with these people. How can one province have so many different customs! Some Mountain People wore huge earrings. Some didn't bathe themselves in their whole lives; in other places, the people were neat and clean. In many villages, we couldn't understand anything that they said. When I got to Taiwan, I realized that the Mountain People here are very much like them, even in the way they tie bands around their heads.

In their mountains, even if we were empty-handed, we could not outpace them; when they were on our flat ground, they could not outpace us, even if we were hoisting heavy loads, because, they said, their feet felt floating, unstable, down on the plains.

The mountain girls were pretty, but the men were too dark to be called good-looking. The girls stayed at home, and didn't work outside, so they remained fair. As long as we behaved ourselves politely and did nothing improper, the people entertained us well, and we were safe. But their men each carried a long knife just in case. Some mountain paths led to just one

7. Non-Chinese ethnic minorities; Mountain People of south China. 


\section{Chinese Working-Class Lives}

house, but if you asked people the way, they told you honestly which were the main paths. Some villages took two or three days' walk to reach. Peddlers like us usually hired a guide who knew all the routes from long experience.

We used to start into the mountains between the second and fourth lunar month. We just kept walking, doing business along the way, till the end of the lunar year, when we'd reach home again. We sold cotton cloth sometimes, but mostly needles, thread, cosmetics-light goods. We'd walk a long way for only one household sometimes, and even then might sell only two or three little things. It was hard work. They didn't use paper money, only silver coins.

Within the mountains was an inner plain, a hilly area. Rivers ran through, so with transportation better, people were able to buy goods from other sources. They were richer, too, planting corn, sweet potatoes, and taro, but no rice. We'd visit them too, and they fed and housed us free because they said we only came once a year, and they didn't need our money.

We didn't earn much from this kind of business, but still the girls criticized our high prices. What we bought was not cheap, and we couldn't sell very dear in remote areas. We had to make a profit over what we spent on keeping ourselves. Except for what we spent at inns, we kept every coin. Nowadays, children spend what they earn pretty freely, but we sweated so for our profits that we didn't want to spend them unless there was some real need. The bundles we carried on our backs were very big, and coming home at the end of the year we always ran into snow. We couldn't see the roads and nearly froze our feet, though we wrapped them up in whatever was left of the cloth. It wasn't easy to earn that money. Working out there for half a year, we earned between half a year and a year's food as profit. It was better than farming.

At home in the village, my family members farmed our land. In those days, villages were very large, with thousands of people. They grew wet rice and some vegetables. When it wasn't too dry and the harvest was good, one year's harvest would provide three years' food. Then we were rich. But rural life is hard; it takes time to get used to it. Even women were expected to do some outdoor work, the way a bride must carry water to the household the day after the wedding. But most outdoor work was done by men, with women permitted to help only with planting and harvesting. Their usual job was to carry water and feed the cows and pigs. Rich families kept many cows and pigs, which required a lot of water carrying. Even one pail is heavy. In the countryside, though women didn't go to school, boys could, depending on their interest. I went for two years, but I didn't learn much 
and am now nearly illiterate. I can remember playing on the way to school and the beatings I got better than any of the books! The children of the rich were sent to town for junior school, and a few to senior school. Girls stayed at home, and most boys worked on the farm.

In those days, lunar New Year was our gayest time. We got a set of new clothes (which we wore till they were worn out), and people killed the chickens, ducks, and pigs they had raised. Chickens were dried so that they kept till the seventh month; fish were smoked. Before New Year's, we put away enough salt, oil, and special foods to last the year, so we didn't have to buy them frequently, for rural markets met only every three days. One of our local customs was for married sisters to come home around New Year. We made special glutinous rice cakes for them-so many that we were still eating them in the third month. We'd fry a couple for breakfast before work every day. Ordinary people didn't have fish or duck to preserve, but they salted, dried, or stored their vegetables. Common people were very frugal then, depending on rice for most of their food. Lard was a treat, and we didn't eat fowl unless we had guests visiting us. Ordinary food consisted of rice with a sauce of chiles, soy sauce, and salt. Families with young boys sent them to the canals to catch fish, which counted as little feasts. It wasn't like it is now, with people eating oil all day, eating this good thing and that.

During the year, we could rest only between the last harvest in the eleventh month until the end of the New Year celebrations in the first month. Then the farmers ploughed again like mules, never stopping. Men worked like this till they were my age now, when they had accumulated something, and had grown sons and daughters-in-law. Then they could retire, have fewer burdens, play cards. If they had no sons, though, only daughters, they would have to keep on through their sixties. If the fields weren't tilled every year, they were ruined as big weeds got into them.

Farming is hard, so I gave it up after one year. Every day, hauling things. In dry weather like this, the crops would wither in the field and there'd be no harvest at all. At harvest, it was a rush. Everything had to be brought in at once, or crops would be lost. You needed additional workers, but they were hard to hire. You had to give them a variety of foods to eat, pay them, and treat them well, or they wouldn't stay. It was like a military campaign, when all the rice turned yellow and had to be harvested at once. Americans use machines, but we did it all with big knives and our backs, with no rest for anyone. To thresh the rice, a man stood at each corner of the threshing floor, each striking alternately with a big flail. Women cut the grain, men carried and threshed it. The baskets of rice weighing about one hundred kilos were carried by men in their twenties. It was best to have lots of brothers. 


\section{Chinese Working-Class Lives}

Our village had one rich family that owned thousands of $m u^{8}$ of land. They sent one of their sons to middle school in Liuzhou City. This was during the warlord period, and the son got a position supplying foodstuffs and horses to the warlord. He came back once, riding a horse very arrogantly, like a god. I wonder what happened to them when the Communists came!

After I was seventeen, I was considered an adult. Before that, boys and girls could play together, but afterwards, it was not permitted. We could just smile in passing. In our area, people married at nineteen or twenty. $\mathrm{My}$ relatives told me in three or four years I should marry and build a house, but I would have to wait till then. I wanted to save money for my marriage, not wanting to be a burden to my relatives, so I left home and went to work as a porter for three or four years at the harbor in Liuzhou.

Except for children in rich families who had daughters-in-law and servants, boys learned how to carry goods with a shoulder pole. There is always lots to carry on a farm, especially in Guangxi, where we didn't have ox carts or horse carts. We didn't even have roads, except for the little paths on the dikes between paddy fields, so men carried everything. Down in the city they needed porters, too. There were few water sources, so rich families, barbershops, and restaurants all needed to have water carried.

After working a few years at this, I began my military service. Most families didn't send their sons into the military. Boys who had no parents, or who wouldn't obey their parents but just followed their own inclinations, were the only ones who became soldiers. Good men did not become soldiers in those days; now, of course, it is different. The best go into service.

What I entered was a warlord's local militia. There was no fighting, and those soldiers ate well and had good clothing. There was nothing to do all day, yet we got a salary. The men weren't like real military men, as we came to be later, but more like common people. There was no draft then-that didn't begin for years.

In 1936 we began to hear of incursions by the Japanese in Guangdong and Guangxi. The Guangdong region still wasn't controlled by the national government, because warlords controlled some areas, and there were Communist bandits in the hills. By 1938, though, the whole country was united under our present government, except for a few small nests of Communist bandits. Military troops were few then-only 600,000 men and women in Guangxi under General Bai Chongxi. The draft began. Ordinary people didn't know what was happening, but we knew the Japanese wanted to fight

8. A $m u$ is approximately one-sixth of an acre in Taiwan.

[136] 
us. There was no television, and few newspapers, so some universities sent students to inform the people that the Japanese were attacking us here and in other parts of China. I decided to join the army, spending 1938 to 1939 in Sichuan with that service. I was stationed with an air force unit, and was able to gain an apprenticeship with them.

There was no exam at first for entering the air force, though when the war with Japan started they began to examine applicants. When I joined, they were glad just to have volunteers. At that time, there were about 300,000 men in the air force; if they all had to pass an exam, there wouldn't have been enough people. It wasn't necessary to have any book learning to do the routine work we were trained in, like removing screws. At some levels, of course, specialists had to be able to read technical materials.

My training as a mechanic was easy. I worked in a group where each person learned a certain part of the aircraft and was responsible for replacing it if there were defects. Each person did his own part and didn't learn about anyone else's. We didn't have to make any judgments. "If something is worn out, take it out and replace it," they told us. One plane was maintained jointly by a team in this way. Engineers from companies that built the planes were responsible for supervision and for solving problems we couldn't handle. We needed to learn from them what was standard or normal, and what counted as defective, what we should do if a part sat too high or low. If anything was abnormal, we told our group head. The condition of each part was recorded in a book. When everything checked out, we could send the plane on as available for flight. The flight-availability group then signed off each plane, took responsibility for it. If anything went wrong with a plane, and they had signed it off as ready for use, the responsibility was theirs. The whole system worked like this, with equipment carefully checked and responsibility divided in an orderly way.

We usually spent the morning inspecting planes, though during the war Japanese bombers might come at any time and disrupt everything. Sometimes the sirens blew ten times a day, and we'd spend the whole day running for cover.

During the war, life was good for me. Food was ample, the conditions of life were orderly. I went to the airport to work every day as dawn broke, and came back to barracks every evening at eight or nine o'clock. It was physically much easier then peddling or farming, and I liked to work with airplanes and machines. There was no place to spend money, so I saved some. I was single and young and had no responsibilities or duties, outside my work. I traveled with my unit, spending time in Sichuan, Xian, Nanjing, and Qingdao. There was nothing else I really wanted to do, just fight the Japanese. 
During the war it was better to be in the air force than in the army, though even in the air force it was hard sometimes. The army had so many soldiers that they sometimes didn't get their food on time, and often didn't get paid. Sometimes in the army, troops were surrounded, so there was no way to supply them. Even if they were flown in, their provisions might be dropped at the wrong place, and taken by the enemy. In the air force, it was all right after you got used to it. Though things were always in short supply, our officers took care of us, getting us food no matter what it took.

Life is full of bitterness, sweetness, and sourness. Each generation's situation is different. Children born today in peacetime enjoy real plenty. After the war began, it was better for us. There were no places to go for entertainment or any kind of recreation. Those who were highly educated could get away from the war; the rest of us just had to follow the military troops.

If it hadn't been for the war, most people would have stayed at home in their own provinces, working on the farm or being laborers. They wouldn't have traveled far-certainly not to Taiwan! When I was small, I heard older people talk of Fujian and Taiwan as the frontiers of China, but I didn't know what direction or how far away they were. Even businessmen rarely traveled from this province to that province, just going from one city to another in the counties surrounding their hometown. Only the biggest merchants went from one province to another and knew about distant places. People who traveled out of their own province were called "outside provincers," exactly as the Taiwanese call us here, instead of calling us "Chinese."

Travel was very difficult during the war. The roads in Sichuan were especially twisty, with roads hairpinning up the mountains, very narrow and dangerous. Cars had to drive so slowly that it took less time to walk if you cut across the loops and just went straight up to the hills. The government built a lot of roads during the war. They were built without machines, all by human labor. In Sichuan I saw an airport being built where hundreds of thousands of people had been brought in to work. Stones were broken up with hammers to a standard size to pave it. America sent some good materials for that airport. The surface had to be strong enough to support the big planes safely. The construction lasted for a long time. People swarmed like ants-you couldn't see the ground for people. Marines, soldiers, air force men, and civilians all gathered there to collect stones. Each household had to collect so many kilos from the riverside. The food for all those people was brought in every day by ten big trucks full of rice baskets.

The mainland is so large that it took years to build just one railway. When I was in Guangxi, I didn't know how large it was, having never seen a map. 


\section{Home and Family}

Even now, if you ask me how big Taiwan is, I couldn't tell you. I have a sense for which places are larger and which smaller, from things I've heard other people say, but I know our Mainland is one of the biggest countries on earth.

In 1945 the Japanese surrendered. Our capital returned to Nanjing, where I was sent for two years. We were still at war, this time with the Communists, so in 1948 I was sent to Qingdao to our biggest air base in the north.

After the victory over Japan, if a man had the chance he went home to see his wife, if he had one, or to get married. Everyone wanted to get married, but for some it was too far to go home. Then he would marry a local girl. Especially while we were stationed in Xian a lot of fellows married local girls. Sometimes their parents wrote and urged them to come home to find a wife because their own women spoke the right language. At that time, however, the women's families weren't so fussy about the men's backgrounds, about whether the two families were well matched. If a man earned a steady salary by serving the country, that was good enough, and the families didn't ask for brideprice. Some of us got good women, which was good for us. Others had bad luck.

The Communists had us pretty much cut off in Qingdao, so it wasn't easy to send mail home. Roads, waterways, airlines-all were cut off. The first two letters I sent home-I had them written for me by a letter writernever arrived. I wanted to tell my relatives I would go home to get married and asked my cousin and his wife to help me find a girl. But I had to wait till the married men had returned from their home leave before I could take mine. I sent another letter, containing pictures and several thousand yuan, which they got. At the time, a thousand yuan would buy many hundredkilo baskets of rice. If they wanted money, they should let me know, I told them. They wrote back, saying they didn't need money, but I should come home to get married. They wrote to say they would wait for my return to make marriage arrangements.

About sending mail on the mainland at the time: it was very difficult and slow. We wrote to our relatives in care of some person in the rural market nearest our home. There were no proper addresses. Then the letter waited till one of our friends or relatives came to the market, and asked about letters from us. If you were sending money, of course you needed trustworthy friends. From the time I sent a letter until the time I received their answer took half a year. The fastest time was about three months. During the Sino-Japanese war, sometimes you just couldn't get through, or the letters had to go by very indirect routes. Sometimes it caused a lot of worry. Money arrived even more slowly because we always sent it person-to- 


\section{Chinese Working-Class Lives}

person. The post office placed a one-thousand-yuan limit on the amount sent, so you could not cash big postal orders easily. In 1949, after we arrived in Taiwan, I wrote back once. After that, all communications were stopped. I know nothing of them now.

In Qingdao my friends were trying to help me to marry. I had some Cantonese workmates who were really good to me. Several of us had rented a couple of rooms where we lived and ate together. We played mah-jongg and enjoyed each other's company. Two others were married to Qingdao girls. One of them said to me, "You're still not married! You'll be an old bachelor." I was twenty-seven, still young, and I knew my relatives wanted me to come home to marry. I said, "I have nothing. How can I marry? I don't care about all that!" I hadn't any savings, just depended for food and clothes on the government. Whether I married would be up to fate; I wasn't going to take any initiative.

Another friend introduced me to a girl, brought us over to her home for a visit. Another's wife promised to introduce me to yet another. The girls worked in the Qingdao textile factories as spinners. I got together with these girls often, after dinner, with our friends. But I had no money and no courage. I was afraid I wouldn't be able to support a wife. As a soldier, I had only what the government gave me and no other ways of getting money. As long as I was single, it didn't matter if I was transferred here and there. But if I had a home I would worry about it. So I delayed another half a year. Every day my friends nagged me about being single.

Finally, someone introduced me to this wife of mine. She was just a little girl, only seventeen, with a tiny face. I said to my friend, who had introduced us, "Don't you think her body's a little lacking?" "Fool," she said, "she's young yet. After she's married, her body will mature."

My friends' wives did all the worrying for me. They invited her to come over when I was back from work. Finally, I told her, "I don't have any money, or much of anything else. I left home when I was young. I can provide you with food, and I have a good character and temperament. These two ladies can vouch for me."

I was asked to go to her home the next day. She had an uncle, her mother's brother, a young brother, and an elder sister. I told her mother clearly, "My two friends can tell you that I have no wife in my home town. I have no money and can't provide your daughter with beautiful clothes, but I will feed her well." And so they agreed to our marriage.

In Qingdao we lived in a two-story house that the government had taken over from the Japanese. It was a very good house for that time. I could get it because there weren't very many of us air force people there then.

Not long after this, we retreated to Taiwan. That was late in 1949. Only 
about a dozen of the men in my group were still unmarried by then. We got some of them married off here, later. The unmarried men came by boat, while those with families were sent ahead by plane. Those who had registered their marriages first went first. The officials' arrangements for our families were good.

My wife became pregnant after only one month of marriage. Our eldest son was conceived on the Mainland. After that we had three other sons, one after another. Unfortunately there was no family planning in those days. Our failures in raising our family are due to this. There is no use in having many children if they are not filial. My wife has been very good, but I haven't given her much of a life. I'm indebted to her.

Raising our sons was not easy, especially after my wife went out to work. I tried to supervise their homework and encourage them to study, but I'm no good with ink and paper. It used to be that if a man worked hard and was loyal, that was enough. Of course, we have to look at today's society, too. Nowadays, young people are not like our generation. We really valued money, planned how to use it, and held on to as much as we could. They eat, drink, amuse themselves, spending without taking any thought for the future. We were always concerned about the future, both saving money for it and trying hard to have enough sons to take care of us when we get old. If a married woman didn't have children, all her in-laws would treat her badly. My wife and I had our children and tried to save money, but our future is still uncertain. Society has changed a great deal.

My wife has described our eldest son's family problems. There is nothing more to say about that. We must try to bring up our grandson, who has our family name and is registered as a Guangxi person, to have a good character.

When my second son died, I could not believe it. We had suffered a lot in earlier years, I had been through the war and was never wounded, and suddenly, he was dead. He gave us a lot of trouble to raise-skipping school, hanging around with Taiwanese hoodlums. He was even in military prison once for fighting with his messmates. He played around with women, gambled, and drank too much. But I kept telling him his future was in the air force, which is the best of the services, the most skilled. Our Mainland people have the say-so in the air force, and we keep the spirit of the nation alive. Finally, he was beginning to settle down, learning his job well and being responsible. Then this.

His death was bad for us all, but his elder brother and I had a further burden to bear. We had to arrange for his death benefits and for his burial in the official cemetery. At first, they wanted to say it was his fault, so there would be no death benefit, and we would have to bury him. 


\section{Chinese Working-Class Lives}

We knew what had happened! That pilot was careless and stupid. Bright Light was doing his job, with no way of knowing some fool would interfere. I am an old soldier. I have given the country my strength and my duty since I was a young man. In everything I have been loyal, so I have no fear. I went from office to office, insisting that my son died honorably. Some people said I should pay someone a little something to smooth the way, but I refused. A father and his four sons have all served this country; we have rights.

Finally, it was all agreed. They paid us NT300,000 (U.S.\$7,500) and buried Bright Light in the highest air force cemetery as a national hero. I am still angry at the pettiness of those officials.

Life has not always been easy for us in the service in Taiwan. There have been good things about life here, but also bad things. When we arrived in 1949, the island was a mess. Americans had bombed the airports and factories and there wasn't much food. We always were fed, and I was paid regularly, but a lot of army people weren't so lucky. There was a lot of sickness in the military camps, with many of the oldest and weakest soldiers dying in the first few years. Many were forced to retire, too, after we had been in Taiwan a few years. Later, it became hard to retire, at least in the air force. If you wanted to get out of the service, you had to bribe someone high up; then you could be released.

All along, though, I was lucky. The air force gave me priority because they really needed us skilled men. Since I was married, I got more pay and rations and better housing. In the fifties, when Taiwan's economy was very backward, the government took care of us, and others envied us our steady salary and secure position. I continued to work at my various postings, just as before. We repaired aircraft for training missions and sometimes for secret reconnaissance flights to the mainland.

It was still wartime- we are at war with the Communist bandits even now-but it was also a kind of peace. Many of the men got slack, and our work was less good. While my wife was working in Taibei all those years, she could have flown free on military transport to come home on her days off, but I wouldn't let her. By then, it had got too dangerous. We had a lot of crashes. They don't always put them in the newspapers, but they were frequent. When we went to the air force cemetery to bury my son, I saw all the graves of our young Mainlander airmen who had died in the line of duty since we came to Taiwan. There are hundreds. It's terrible. That is partly the responsibility of the mechanics. That kind of thing made me feel less and less satisfied with being in our service.

Also, in the early sixties I was beginning to have back trouble. In the old American planes equipped for parachute drops, there's a spring mechanism 
for releasing the parachutes from the plane. Because we Chinese are shorter than Americans, we had to use our legs, lying on our backs, to retract the springs. This is really bad for the lower back; a lot of the men have been injured by doing it. My back got so bad, I had some X-rays, which showed some cracked vertebrae.

Consequently, they asked me to retire. I didn't want to, because I wasn't fifty-five yet, the earliest age at which I could get a pension. We argued it back and forth. They said also the newer equipment was all marked in English and more complicated, so we old soldiers weren't any use in fixing it. They let me stay till fifty-five, though, and then I retired.

The pension I got was very small-NT $\$ 40,000$ (U.S. $\$ 1,000$ ) a year. We could have lived on it but could not have helped our children. In those days, when our boys in Taiwan went into their compulsory three years of service, they earned practically nothing. If they wanted to come home for a visit, or buy an occasional good meal, or a piece of civilian clothing, they had to get money from home. We had sons studying and in the service, so we needed the money. My back was very bad, and I can't speak any Taiwanese, so in our small town I didn't see how I could find any work as a mechanic. If we moved to a bigger town, we could not live in our house, but would have to rent one, which would have been expensive. And anyway, I didn't want to be somebody's employee. I've been a soldier all my life, and I'm an old man. I'd lose face to bow and scrape for some boss. So I managed the boys and the house, and now I'm looking after our grandson!

Here in our air force neighborhood, there are men and women from all over China. Some are my old comrades-in-arms, some are fellow provincials of my wife or myself. I see my friends often-someone is always dropping in for a cigarette or a simple meal. I play cards or mah-jongg sometimes, or just chat. There's a lot of gossip in a place like this, though, and it makes me furious when I hear this one and that one talking about everyone's private business. My son's divorce was a real scandal around here at the time, because divorce almost never happened in the past. Now many families have such embarrassments.

When I think back about my career in our country's air force, I have mixed feelings. Some of our leaders were very great men. Our old president, Jiang Jieshi, was one of this century's greatest men. I was proud to follow him. But below him there are others-all divided into factions that don't always put the country first. Some are corrupt. I have never paid attention to politics because I'm just an ordinary soldier, doing my job. National affairs are none of my business. But I can say that since we have been in Taiwan, morale has been worse, our work is not done as well as 


\section{Chinese Working-Class Lives}

before, and we old loyal families have fallen behind everyone else. Everyone is getting rich but us. I lost my own family because I followed our old president to Taiwan; but in Taiwan the family my wife and I founded is a modern family, all scattered and independent. We can never know what will become of us, only accept our fate. 